\title{
Adaptation of Work-Related Rumination Scale into Turkish *
}

\author{
Bilge SULAK AKYÜZ **
}

Sema SULAK ***

\begin{abstract}
The aim of the present study was to investigate the validity and reliability of the Turkish version of Work-Related Rumination Scale (T-WRRS). The study was conducted sampling 582 white-collar workers from various fields. In order to determine the construct validity, confirmatory factor analysis was conducted. Additionally, Cronbach Alpha values as an indicator of internal consistency and item-total correlations were utilized for reliability analysis. The results yielded that the Turkish version of WRRS is a reliable scale with three-factor, and it can be used to measure work-related rumination among Turkish workers.
\end{abstract}

Key Words: Work-related rumination, rumination, validation study, CFA.

\section{INTRODUCTION}

Throughout a workday, individuals encounter various emotional, cognitive, and physical demands. At the end of a workday, individuals might feel emotional fatigue due to consuming all the energy levels. In order to reoperate the next day, individuals need to rest and replenish their energy level. After work, time needs to be for individuals to disengage from duties related to work. However, for some individuals, this activity cannot be accomplished as a result of high demands. The process to interfere with successful disengagement from work is called rumination (Cropley, Dijk, \& Stanley, 2006; Roger \& Jamieson 1988). Previous research in relation to rumination has mainly derived from clinical psychology, and the focus was predominantly on the emotional feature of rumination. NolenHoeksema, Wisco, and Lyubomirsky (2008) defined rumination as a recurring thinking process that focuses on distress symptoms and attention is given to the feelings related to the issues. In addition, Martin and Tesser (1996) defined rumination as "a class of conscious thoughts that revolve around a common instrumental theme, and that recur in the absence of immediate environmental demands requiring the thoughts" (as cited in Cropley \& Zijlstra, 2011, p. 6). Taken together it can be said that rumination can be mainly about issues related to self, stressful events, or psychological symptoms one has. Rumination is giving attention to the symptoms/stressors, focusing on the possible reasons and outcomes of these symptoms / stressors. Previous studies indicated that rumination was related to several psychological problem such as depression (Lyubomirsky, Caldwall, \& Nolen-Hoeksema, 1998; Thomsen, Mehlsen, Christensen \& Zachariae, 2003), anxiety (Mellings \& Alden, 2000), anger (Hogan \& Linden, 2004), poor sleep quality (Thomsen et al., 2003), and somatic symptoms (Brosschot \& Van Der Doef, 2006).

Although research in relation to how individuals ruminate about work has not been studied until recently, occupational psychology has given attention to this phenomenon. Sonnentag and Bayer (2005) said occupational psychology focused on thinking about work during leisure time and assessed the detachment from work. Cropley and Zijlstra (2011) speculated that unlike traditional rumination, which was mainly about emotional aspects, work-related rumination includes both affective and cognitive aspects. In general, when individuals ruminate, they tend not to have solutions for the problems they have (Nolen-Hoeksema,1987); however, Cropley and Zijlstra opposed to this indicating ruminating about problem(s) can be helpful for individuals. In line with growing interest on this topic, Cropley and Zijlstra (2011) defined work-related rumination as "Work-related rumination may be

\footnotetext{
* This study was funded by Bartin University Coordination of Scientific Research Projects. Project no: 2016-SOS-A-018. ** Assist. Prof. PhD., Bartın University, Faculty of Education, Bartın-Turkey, bsakyuz@ bartin.edu.tr, ORCID ID: 00000003-3044-3622

*** Assist. Prof. PhD., Bartın University, Faculty of Education, Bartın-Turkey, semasulak@gmail.com, ORCID ID: 00000002-2849-321X
}

To cite this article:

Sulak-Akyüz, B., \& Sulak, S. (2019). Adaptation of work-related rumination scale into Turkish. Journal of Measurement and Evaluation in Education and Psychology, 10(3), 422-434. doi: 10.21031/epod.542872 
considered as a thought or thoughts directed to issues relating to work, that is / are repetitive in nature" (p. 6). Individuals ruminate about work in relation to tasks that were not completed, problems that were not solved, and issues that were not clarified with colleagues (Querstret \& Cropley, 2012). Thus, work-related rumination is not only related to past related issues but also related to future-oriented demands / issues. Considering the fact that work and work-related tasks take more than one-third of a day (Cropley \& Zijlstra, 2011), it is expected for individuals to ruminate about work and work-related issues. Hence work-related rumination has traits of both traditional rumination due to focusing on past issues as well as traits of worry due to focusing on futuristic events / issues (Flaxman, Menard, Bond \& Kinman, 2012).

Over the years, researchers attempted to explore work-related rumination via various instruments. In an instrument developed by Warr (1990), there is a subscale aiming at investigating work strain. After more than a decade, Cropley and Millward-Purvis (2003) developed a three items measure that explores the switching off from work process. In the following years, Sonnentag and Fritz (2007) constructed and proposed an instrument, and one of the sub-scales of the instrument addressed detachment from work. Even though previous research supported the idea that work-related rumination has negative consequences, Cropley and Zijlstra (2011) argued otherwise indicating "However thinking and reflecting about work issues can also have beneficial effects and can be associated with positive connotations" (p. 10). As a result, the authors further proposed three distinct types of work-related rumination, which are affective rumination, problem-solving pondering, and detachment. Affective rumination is described as thinking negatively, disturbingly, and persistently about work, which manifests unwanted emotions (Pravettoni, Cropley, Leotta \& Bagnara, 2007). Problem-solving pondering, on the other hand, is prolonged thinking about a work-related problem or evaluating solutions on how it can be improved that does not evoke emotional arousal. Finally, detachment is the ease to leave work behind (Cropley \& Zijlstra, 2011). In 2012, Cropley, Michalianou, Pravettoni, and Millward utilized this three-factor conceptualization and developed a work-related rumination questionnaire. The aim of the questionnaire is to investigate how people think about work-related issues (Cropley \& Zijlstra, 2011).

The aforementioned questionnaire was utilized in several researches. In a study aiming at investigating the relationship between work-related rumination, sleep quality, and work-related fatigue, the three factors structure of the instrument was supported (Querstret \& Cropley, 2012). Moreover, affective rumination factor was confirmed via a study investigating the impacts of work-related rumination and recovery on sleep and workplace incivility (Demsky, Fritz, Hammer \& Black, 2018). While workrelated rumination questionnaire was widely utilized in English, it was translated into other languages. Syrek Weigelt, Peifer and Antoni (2017) conducted a study using the German translation of workrelated rumination questionnaire that examined the indirect link between unfinished tasks and sleep by affective rumination and problem-solving pondering. Moreover, in another study aiming at investigating how affective rumination and problem-solving pondering impact overall wellbeing, the Persian translation of work-related rumination questionnaire was utilized (Firoozabadi, Uitdewilligen, \& Zijlstra, 2018). According to the results of these two studies, affective rumination and problemsolving are two distinct factors.

\section{Purpose of the Study}

Several rumination instruments have been translated into Turkish (Erdur-Baker \& Bugay, 2010; ErdurBaker \& Bugay, 2012; Karatepe, Yavuz \& Türkcan, 2013); however, these translated instruments mainly focused on traditional rumination that focuses on experiences happened in the past and mostly on distress symptoms of individuals, namely emotional aspects of rumination. However, work-related rumination is a combination of both past and future-oriented rumination. As a result, utilizing these instruments to assess work-related rumination can be detrimental. There might be several triggers in relation to work-related rumination. Querstret and Cropley (2012) indicated that some individuals think about unfinished tasks while others ponder about a problem that needs to be addressed, and others might evaluate unwanted issues at work or their relationship with their colleagues. Previous research has been conducted in relation to work-related rumination and various other variables; such 
as sleep disturbances (Cropley et al., 2006; Querstret, Cropley, \& Fife-Schaw, 2016; Querstret, Cropley, Kruger \& Heron, 2015; Syrek et al., 2017), fatigue (Querstret \& Cropley, 2012; Querstret et al., 2015; Querstret et al., 2016), exhaustion (Donahue et al., 2012; Firoozabadi et al., 2018), depression (Hamesch, Cropley \& Lang, 2014), cortisol level (Cropley Rydstedt, Devereux, and Middleton, 2013; Rydstedt, Cropley, Devereux \& Michalianou, 2009), well-being (Firoozabadi et al., 2018; Hamesch et al., 2014; Querstret \& Cropley, 2012; Syrek et al., 2017), work stressors (Hamesch et al., 2014), work beliefs (Zoupanou, Cropley, \& Rydstedt, 2013), unwinding process (Cropley \& Millward, 2009), and job strain (Cropley et al., 2006; Cropley \& Millward-Purvis, 2003). Thus, in the absence of a Turkish Work-Related Rumination Scale (T-WRRS), it is not possible to garner further information about Turkish workers' rumination traits. Moreover, work-related rumination is a recent phenomenon in literature, and there is no known study in Turkish literature in relation to work-related rumination. Hence, it is crucial to translate and adapt the WRRS into Turkish in order to explore possible underlying and associated factors that are related to work-related rumination. Therefore, the aim of the current study is to translate and adapt work-related scale as well as to examine the factor structure of the scale with Turkish sample. Additionally, this study will contribute to the body of research by adding an instrument that can be utilized by researchers in this field.

\section{METHOD}

This study aimed at translating work-reated rumination scale into Turkish. In this section the participants, data collection procedure, data collection tool, and the data analysis were described.

\section{Participants}

A total of 582 while-collar workers were included in the study. The demographics of participants were shown in Table 1.

Table 1. Demographic Properties of Participants

\begin{tabular}{llll}
\hline & & $\mathbf{N}$ & $\mathbf{\%}$ \\
\hline Gender & Female & 262 & 45.0 \\
& Male & 320 & 55.0 \\
\hline Organization & Public & 294 & 50.5 \\
& Private & 288 & 49.5 \\
\hline Age $(\mathrm{M} \pm$ S.D.) & & $35.64 \pm 9.995$ & \\
Daily working hour (M \pm S.D.) & & $9.10 \pm 2.721$ & \\
Year of work (M \pm S.D.) & & $10.45 \pm 9.392$ & \\
\hline
\end{tabular}

Cropley et al. (2012) specified white-collar workers as full-time employees from administration, banking, education, health, information technology, marketing, research/science, retail, human resources, insurance, and consultancy. Current study followed similar path, and the occupation composition of the participants was teacher (17.4\%), retail (7.6\%), administrator (6.9\%), soldier / policeman $(6.9 \%)$, engineer $(6.4 \%)$, nurse $(5.8 \%)$, medical professionals $(5.7 \%)$, human resources (5.5\%), officer (4.8\%), doctor (4\%), accountant (3.6\%), businessman (3.4\%), pharmacist $(2.7 \%)$, information technology specialist (2.6\%), attorney (2.2\%), banking/finance (2.1\%), social worker $(1.5 \%)$, architect $(1.4 \%)$, veterinarian $(1.2 \%)$, faculty $(1 \%)$, and other $(7.4 \%$, i.e. insurance agent, technician, journalist, author, cosmetician, secretary and operator). Participants were predominantly from Bartın. Remaining participants were from other cities of Turkey (İstanbul, Ankara, Amasya, Düzce, Kütahya, Isparta, Samsun, Antalya) and reached out through personal communications via snowballing effect. 


\section{Data Collection Instrument}

\section{Work-related rumination scale}

The scale was developed by Cropley et al. (2012). The factor structure of the work-related scale was tested in a study aiming at investigating the relationship between work-related rumination and food choice. In this study, a total number of 268 participants from administration, banking / finance, consultancy, education, health, human resources, insurance, information technology, marketing, retail, and research / science were sampled. The age of the participants ranged from 19 to 63 . The scale has twenty-five questions using a 5-point Likert scale $(1=$ very seldom or never, $2=$ seldom, $3=$ sometimes, $4=$ often and $5=$ very often or always). According to the factor analysis, three factors emerged accounting for nearly $70 \%$ of the variance with eigenvalues greater than one. Concerning oblimin rotation, the variables having .40 or higher loads were retained; this resulted variables on a single factor (Cropley et al., 2012). The results are presented in Table 2.

Table 2. Work-Related Rumination Scale Factor Loadings

\begin{tabular}{|c|c|c|c|}
\hline & Factor 1 & Factor 2 & Factor 3 \\
\hline \multicolumn{4}{|l|}{ Affective Rumination } \\
\hline Q1 & .75 & .12 & -.10 \\
\hline Q15 & .93 & -.15 & .14 \\
\hline Q9 & .78 & .05 & -.11 \\
\hline Q7 & .68 & .06 & -.20 \\
\hline Q5 & .67 & .19 & -.21 \\
\hline \multicolumn{4}{|l|}{ Problem-Solving Pondering } \\
\hline Q8 & .26 & .60 & -.17 \\
\hline Q4 & .40 & .62 & -.03 \\
\hline Q13 & .29 & .62 & -.08 \\
\hline Q11 & -.34 & .86 & .04 \\
\hline Q2 & .06 & .79 & .02 \\
\hline \multicolumn{4}{|l|}{ Detachment } \\
\hline Q6 & -.37 & -.20 & .41 \\
\hline Q10 & .10 & .01 & .78 \\
\hline Q14 & -.02 & .13 & .88 \\
\hline Q3 & -.03 & -.01 & .83 \\
\hline Q12 & -.08 & -.10 & .78 \\
\hline Eigenvalues & 7.30 & 1.79 & 1.32 \\
\hline$\%$ of Explained Variance & 48.72 & 11.97 & 8.82 \\
\hline Cronbach's Alpha & .90 & .82 & .86 \\
\hline
\end{tabular}

Note: Factor loadings > .40 are in boldface. (M. Cropley, personal communication, January 25, 2016)

The final scale had 15 items with three factors each of which had five questions. Among all items only item 6 is reverse coded. The first factor was called "affective rumination" that is defined as emotional experiences of work-related thoughts (e.g. "Do you become tense when you think about work-related issues during your free time?"; "Are you troubled by work-related issues when not at work?"). The second factor was called "problem-solving pondering" which was defined as thinking and reflecting about work-related issues (e.g. "In my free time I find myself reevaluating something I have done at work", "I find solutions to work-related problems in my free time"). Finally, the third factor was called "detachment" that was defined as the ability to switch off from work (e.g. "Do you find it easy to unwind after work?", "Do you leave work issues behind when you leave work?'). Cronbach's Alphas were reported .90 for affective rumination, .82 for problem-solving pondering, and .86 for detachment, respectively (Cropley et al., 2012). Querstret and Cropley (2012) confirmed three factors for the scale, indicating nearly $70 \%$ of the variance was explained by three factors. They reported Cronbach's Alpha .90 for affective rumination, .81 for problem-solving pondering, and .88 for detachment. In a study utilizing German translation of the scale, Syrek et al. (2017) reported Cronbach's Alphas .91 for affective rumination and .84 for problem-solving pondering. They further indicated two-factor model 
was better in comparison to one-factor model. According to the results of a study using Persian translation of the scale, Firoozabadi et al. (2018) reported Cronbach's Alphas as .91 and .89 for affective rumination and problem-solving pondering, respectively. The authors further indicated in comparison to one-factor model two-factor model was a better fit.

\section{Data Collection Procedure}

Prior to translating the instrument, the required permission was taken from the original author of the scale via e-mail. The original scale was translated into Turkish by three experts. Of the experts one of them is specialized in translation and interpretation, the other one is specialized in English literacy, and the last one is specialized in clinical counseling with good command of English. After the translation was completed, the researchers finalized the Turkish version of the scale. In the next step, back translation into English was conducted by an expert in the field of teaching English as a second language. In order to assess the language compatibility, comprehensibility, and clarity of the items, expert consultation was utilized. Experts recommended using my work instead of work due to language connotations because in Turkish the word work cannot be interpreted as a profession. Another recommendation was to use thinking on / about instead of reevaluating in order to provide better comprehensibility. Taken into consideration all the recommendations, the scale was finalized, and the pilot study was conducted for reliability and validity.

\section{Data Analysis}

In order to test the language validity of the scale, English and Turkish versions were administered to the same participants. As a result, Spearman-Brown correlation coefficient was calculated. Furthermore, construct validity was tested utilizing Confirmatory Factor Analysis (CFA). Finally, for internal consistency Cronbach Alpha was used.

\section{RESULTS}

\section{Validity Results}

\section{Language validity}

The original and the Turkish version of the WRRS were administered in three weeks intervals to the same participants $(\mathrm{N}=16)$ who were faculty members and had good English proficiency. Spearman Brown correlation coefficient results yielded that these two administrations were correlated for affective rumination $(\mathrm{r}=.85 ; p<.05)$, problem solving pondering $(\mathrm{r}=.73 ; p<.05)$ and detachment $(\mathrm{r}$ $=.62, p<.05)$. This result indicated that the T-WRRS had language validity.

\section{Confirmatory factor analysis}

In order to evaluate whether the statistical analysis met the criteria, confirmatory factor analysis assumptions were tested which were determining missing data and outliers, sample size, multicollinearity, and examining univariate as well as multivariate normality (Tabachnick \& Fidell, 2001; Ullman, 2012).

The data was collected from 607 participants, and it was screened for possible coding errors and missing values for the analysis. Of the participants, eleven of them were excluded from the analysis due to having inaccurate information. Moreover, fourteen outliers were detected and removed from the data set utilizing box plots. Hence, a total of 582 participants were included in the analysis. 
Despite there is no consensus regarding what constitutes adequate sample size for CFA; Klein (2005) said that the parameter and observation ratio needs to be at least 10:1, and Worthington and Whittaker (2006) said that sample size $300 \geq$ is acceptable. Thus, sample size $(\mathrm{N}=582)$ is adequate for conducting CFA.

In order to test multicollinearity assumption, VIF and tolerance $(\mathrm{T})$ indices were utilized. In the data set VIF value was found to be lower than 10, and $\mathrm{T}$ value was different than zero. This result was indicative of no multicollinearity (Hair, Black, Babin, Anderson \& Tatham, 2014).

Concerning normality, the univariate normality assumption was tested utilizing skewness and kurtosis values as well as their critical ratios. According to the results, skewness values ranged from -0.569 to 0.498 and kurtosis values ranged from -1.111 to -0.363 . Schumacker and Lomax (2004) indicated that if skewness and kurtosis values are between \pm 1.5 , the data is distributed normally. This result indicated a normal distribution. Furthermore, maximum likelihood estimation method requires multivariate normally distributed data (Bollen, 1989 as cited in Byrne, 2010; Brown \& Moore, 2012; Byrne, 2010). Although there are various measures to test multivariate normality, Mardia's (1970) measure is the widely utilized one. According to Mardia if $\mathrm{p}$ values for skewness and kurtosis are greater than .05 , multivariate normality is met (Cain, Zhang, \& Yuan, 2016). In current study $\mathrm{p}$ values were found to be greater than .05 , so it can be said the data was clearly multivariate normal.

CFA was conducted sampling 582 participants using IBM SPSS and AMOS 23 software. Firstly, CFA model was created using three factors as latent traits as well as items as observed variables. This model was shown in Figure 1.

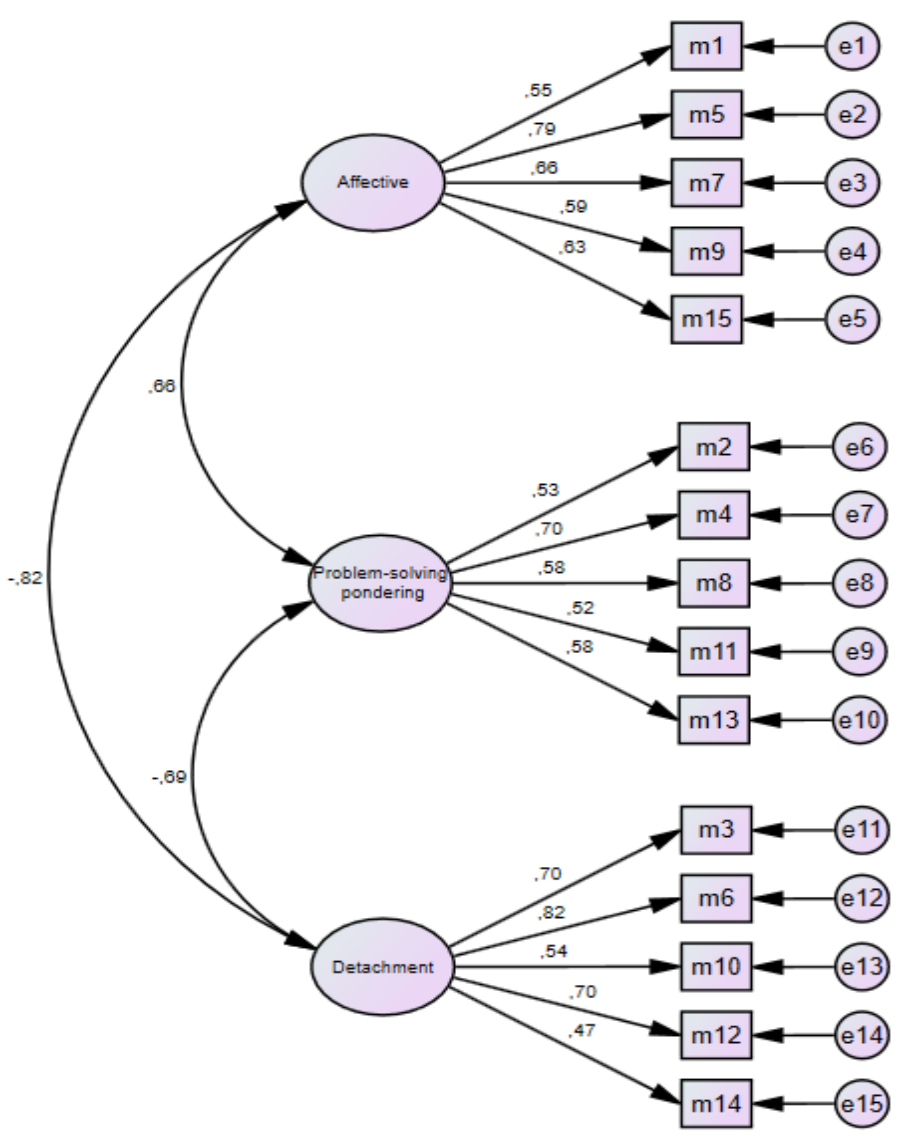

Figure 1. T-WRRS CFA Model

In the second stage, the maximum likelihood method was used in estimating the model. It was aimed to estimate the parameters including the errors of the observed variables, the variances of latent 
variables, and the regression coefficients related to the paths drawn from the latent variables to the observed variables. Parameter's estimated value, standard error, and critical ratio are given in Appendix A.

Lastly, in order to test the adequacy of model fit, a number of fit indices were used. Several researchers reported good and acceptable fit indices for the adequacy of model fit (Hu \& Bentler, 1999; Kline, 2005; Meydan \& Sesen, 2011; Tabachnick \& Fidell, 2001). These aforementioned fit indices as well as present study's fit indices were presented in Table 3.

Table 3. T-WRRS CFA Model Fit Indices and Criterion Values for Good and Acceptable Fit

\begin{tabular}{llll}
\hline Indices & T-WRRS fit indices & Noble Fit & Acceptable Fit \\
\hline$\chi^{2} / \mathrm{df}$ & 4.04 & $0 \leq \chi^{2} / \mathrm{df} \leq 3$ & $3<\chi^{2} / \mathrm{df} \leq 5$ \\
GFI & 0.92 & $.95 \leq \mathrm{GFI} \leq 1$ & $.90 \leq \mathrm{GFI}<.95$ \\
IFI & 0.91 & $.95 \leq \mathrm{IFI} \leq 1$ & $.90 \leq \mathrm{IFI}<.95$ \\
TLI & 0.91 & $.95 \leq \mathrm{TLI} \leq 1$ & $.90 \leq \mathrm{TLI}<.95$ \\
CFI & 0.91 & $.95 \leq \mathrm{CFI} \leq 1$ & $.90 \leq \mathrm{CFI}<.95$ \\
RMSEA & 0.072 & $.00 \leq \mathrm{RMSEA} \leq .05$ & $.05<\mathrm{RMSEA} \leq .08$ \\
SRMR & 0.059 & $.00 \leq \mathrm{SRMR} \leq .05$ & $.05<\mathrm{SRMR} \leq .10$ \\
\hline
\end{tabular}

Note: GFI = Goodness of Fit Index, IFI = Incremental Fit Index, TLI = Tucker-Lewis Index, CFI = Comparative Fit Index, RMSEA $=$ Root Mean Square Error of Approximation, SRMR = Standardized Root Mean Square Residual.

When the fit indices for the present study were compared to good fit and acceptable fit indices criterion, it was concluded that the values $\chi^{2} / \mathrm{df}$, GFI, IFI, TLI, CFI, RMSEA, and SRMR met the criterion for acceptable fit.

\section{Reliability Analysis}

Reliability of the T-WRRS was examined by assessing the internal consistency coefficient Cronbach's Alpha. The reliability results are shown in Table 4.

Table 4. Reliability Analysis Results for T-WRRS

\begin{tabular}{llll}
\hline Sub-Scale & Item No & Item Total Correlation & Cronbach's Alpha \\
\hline \multirow{5}{*}{ Affective rumination } & Q1 & .51 & .79 \\
& Q5 & .60 & \\
& Q7 & .58 & \\
& Q9 & .56 & .73 \\
Problem-solving pondering & Q15 & .59 & \\
& Q4 & .47 & \\
& Q8 & .50 & .79 \\
Q11 & .52 & \\
& Q13 & .50 & \\
\hline \multirow{5}{*}{ Detachment } & Q3 & .45 & \\
& Q6 & .62 & \\
& Q10 & .51 & \\
\hline
\end{tabular}

Nunnally (1978) indicated that the acceptable reliability value is $>.70$. According to the results, Cronbach's Alphas for affective rumination, problem-solving pondering, and detachment were all above .70, which indicates acceptable reliability. Furthermore, item-total scale correlation of .30 or higher was considered acceptable for each item in the scale (Alpar, 2012; Sencan, 2005). It can be seen in Table 4 that all the item-total correlation coefficients were greater than .30 . Hence, all items were retained in the scale. 


\section{DISCUSSION and CONCLUSION}

The aim of the study was to adapt the WRRS into Turkish. For this purpose, factor analysis and reliability analysis were utilized. When item analysis was investigated, it was found that all items in the scale had adequate discrimination. According to confirmatory factor analysis results, current study results yielded three factors; affective rumination, problem-solving pondering, and detachment, which was similar to previous research findings (Cropley et al., 2012; Querstret \& Cropley, 2012). It can be interpreted that Turkish translation factor structure was consistent with the original factor structure. WRRS was translated into German and Persian. According to current study results, factor structure of the scale was similar to German translation (Syrek et al., 2017) as well as Persian translation (Firoozabadi et al., 2018). It can be said that WRRS can be utilized in different cultural contexts and present psychometrically sound results. The reliability procedure of T-WRRS was carried out by the calculation of internal consistency coefficient (Cronbach Alpha). Similar to previous study findings (Cropley et al., 2012; Firoozabadi et al., 2018; Hamesch et al., 2014; Querstret \& Cropley, 2012; Syrek et al., 2017), the results demonstrated high internal consistency estimates for T-WRRS. In sum, it can be said that T-WRRS had adequate psychometric properties and can be utilized in Turkish culture. Additionally, CFA showed adequate model fit for study data providing cross-cultural evidence for the construct validity.

Although future research is required, the current study is assumed to extend the knowledge and research on work-related rumination. The T-WRRS can be utilized by experts in the field of occupational psychology, business, and administration in order to understand and assess workers' work-related rumination traits. Additionally, it is hoped that current results can aid cross-cultural studies. Previous research indicated work-related rumination has several side effects, i.e. fatigue, job strain, and it was suggested that by utilizing T-WRRS these areas, as well as other associations, can be examined in detail. Future research can further knowledge regarding possible associations, antecedents, and consequences of work-related rumination.

Despite the fact that the results of the current study are promising, there are several limitations regarding sampling and analysis. This study sample was limited to white-collar workers. Future research can focus on different samples other than white-collar workers to validate the scale. Moreover, criterion-related validity procedure was not conducted due to the lack of instruments to assess work-related rumination. Hence, further research on the psychometric properties of this scale is needed.

\section{REFERENCES}

Alpar, R. (2012). Uygulamalı istatistik ve gecerlik-güvenirlik. Ankara: Detay Yayıncılık.

Brosschot, J. F., \& Van Der Doef, M. (2006). Daily worrying and somatic health complaints: Testing the effectiveness of a simple worry reduction intervention. Psychology \& Health, 21(1) 19-31. doi: $10.1080 / 14768320500105346$

Brown, T. A., \& Moore, M. T. (2012). Confirmatory factor analysis. In R. H. Hoyle (Ed.), Handbook of structural equation modeling (pp. 361-379). New York, NY: Guilford Press.

Byrne, B. M. (2010). Structural equation modeling with AMOS ( $2^{\text {nd }}$ Ed.). New York, NY: Routledge.

Cain, M. K., Zhang, Z., \& Yuan, K. H. (2016). Univariate and multivariate skewness and kurtosis for measuring nonnormality: prevalence, influence and estimation. Behavioral Research Methods, 49(5), 1716-1735. doi: 10.3758/s13428-016-0814-1

Cropley, M., \& Millward, L. J. (2009). How do individuals "switch-off" from work during leisure? A qualitative description of the unwinding process in high and low ruminators. Leisure Studies, 28(3), 333-347. doi: $10.1080 / 02614360902951682$

Cropley, M., \& Millward-Purvis, L. (2003). Job strain and rumination about work issues during leisure time: A diary study. European Journal of Work Organizational Psychology, 12(3), 195-207. doi: $10.1080 / 13594320344000093$

Cropley, M., \& Zijlstra, F. (2011). Work and rumination. In J. Langan-Fox, \& C. L. Cooper (Eds.). Handbook of stress in the occupations (pp. 487-502). Cheltenhm, UK: Edward Elgar Publishing.

Cropley, M., Dijk, D. J., \& Stanley, N. (2006). Job strain, work rumination, and sleep in school teachers. European Journal of Work Organizational Psychology, 15(2), 181-196. doi: $10.1080 / 13594320500513913$ 
Cropley, M., Michalianou, G., Pravettoni, G., \& Millward, L. (2012). The relation of post-work ruminative thinking with eating behaviour. Stress and Health, 28(1), 23-30. doi: 10.1002/smi.1397

Cropley, M., Rydstedt, L. W., Devereux, J. J., \& Middleton, B. (2013). The relationship between work-related rumination and evening and morning salivary cortisol secretion. Stress and Health, 31(2), 150-157. doi: $10.1002 / \mathrm{smi} .2538$

Demsky, C. A., Fritz, C., Hammer, L. B., \& Black, A. E. (2018). Workplace incivility and employee sleep: The role of rumination and recovery experiences. Journal of Occupational Health Psychology. 24(2), 228240. doi: 10.1037/ocp0000116

Donahue, E. G., Forest, J., Vallerand, R. J., Lemyre, P. N., Crevier-Braud, L., \& Bergeron, É. (2012). Passion for work and emotional exhaustion: The mediating role of rumination and recovery. Applied Psychology: Health and Well-Being, 4, 341-368. doi: 10.1111/j.1758-0854.2012.01078.x

Erdur-Baker, O., \& Bugay, A. (2010). The short version of ruminative response scale: Reliability, validity and its relation to psychological symptoms. Procedia-Social and Behavioral Sciences, 5, 2178-2181. doi: 10.1016/j.sbspro.2010.07.433

Erdur-Baker, O., \& Bugay, A. (2012). The Turkish version of the Ruminative Response Scale: An examination of its reliability and validity. International Journal of Education and Psychology in the Community, $10(2), 1-16$.

Firoozabadi, A., Uitdewilligen, S., \& Zijlstra, F. R. H. (2018). Should you switch off or stay engaged? The consequences of thinking about work on the trajectory of psychological well-being over time. Journal of Occupational Health Psychology, 23(2), 278-288. doi: 10.1037/ocp0000068

Flaxman, P. E., Menard, J., Bond, F. W., \& Kinman, G. (2012). Academics' experiences of a respite from work: Effects of self-critical perfectionism and perseverative cognition on postrespite wellbeing. Journal of Applied Psychology, 97(4), 854-865. doi: 10.1037/a0028055

Hair, J. F., Black, W. C., Babin, B. J., Anderson, R. E., \& Tatham, R. L. (2014). Multivariate data analysis $\left(7^{\text {th }}\right.$ Ed.). Upper Saddle River, NJ: Pearson Prentice Hall.

Hamesch, U., Cropley, M., \& Lang, J. (2014). Emotional versus cognitive rumination: Are they differentially affecting long-term psychological health? The impact of stressors and personality in dental students. Stress and Health, 30(3), 222-231. doi: 10.1002/smi.2602

Hogan, B. E., \& Linden, W. (2004). Anger response styles and blood pressure: At least don't ruminate about it! Annals of Behavioral Medicine, 27(1), 38-49. doi: 10.1207/s15324796abm2701_6

Hu, L. T., \& Bentler, P. M. (1999). Cutoff criteria for fit indexes in covariance structural analysis: Conventional criteria versus new alternatives. Structural Equation Modeling: A Multidisciplinary Journal, 6(1), 1-55. doi: 10.1080/10705519909540118

Karatepe, H. T., Yavuz, F. K., \& Türkcan, A. (2013). Validity and reliability of the Turkish version ruminative thoughts style questionnaire. Bulletin of Clinical Psychopharmacology, 23, 231-241. doi: 10.5455/bcp.20121130122311

Kline, R. B. (2005). Principle and practice of structural equation modelling. New York, NY: Guilford.

Lyubomirsky, S., Caldwell, N. D., \& Nolen-Hoeksema, S. (1998). Effects of ruminative and distracting responses to depressed mood on retrieval of autobiographical memories. Journal of Personality and Social Psychology, 75(1), 166-177. doi: 10.1037/0022-3514.75.1.166

Mardia, K. V. (1970). Measures of multivariate skewness and kurtosis with applications. Biometrika, 57(3), 519530.

Mellings, T. M. B., \& Alden, L. E. (2000). Cognitive processes in social anxiety: The effects of self-focus, rumination and anticipatory processing. Behaviour Research and Therapy, 38, 243-257. doi: 10.1016/S0005-7967(99)00040-6

Meydan, C. H., \& Sesen, H. (2011). Yapısal esitlik modellemesi AMOS uygulamaları. Ankara: Detay Yayıncılık.

Nolen-Hoeksema, S. (1987). Sex differences in unipolar depression: Evidence and theory. Psychological Bulletin, 101(2), 259-282. doi: 10.1037/0033-2909.101.2.259

Nolen-Hoeksema, S., Wisco, B. E., \& Lyubomirsky, S. (2008). Rethinking rumination. Perspectives on Psychological Science, 3(5), 400-424.

Nunnally, J. C. (1978). Psychometric theory (2nd Ed.). New York, NY: McGrawHill.

Pravettoni, G., Cropley, M., Leotta, S. N., \& Bagnara, S. (2007). The differential role of mental rumination among industrial and knowledge workers. Ergonomics, 50(11), 1931-1940. doi: $10.1080 / 00140130701676088$

Querstret, D., \& Cropley, M. (2012). Exploring the relationship between work-related rumination, sleep quality, and work-related fatigue. Journal of Occupational Health Psychology, 17(3), 341-353. doi: $10.1037 / \mathrm{a} 0028552$

Querstret, D., Cropley, M., \& Fife-Schaw, C. (2016). Internet-based instructor-led mindfulness for work-related rumination, fatigue, and sleep: Assessing facets of mindfulness as mechanisms of change. A randomized 
waitlist-controlled trial. Journal of Occupational Health Psychology, 22(2), 153-169. doi: $10.1037 /$ ocp0000028

Querstret, D., Cropley, M., Kruger, P., \& Heron, R. (2015). Assessing the effect of a Cognitive Behaviour Therapy (CBT)-based workshop on work-related rumination, fatigue, and sleep. European Journal of Work and Organizational Psychology, 25(1), 1-18. doi: 10.1080/1359432X.2015.1015516

Roger, D., \& Jamieson, J. (1988). Individual differences in delayed heart-rate recovery following stress: The role of extraversion, neuroticism and emotional control. Personality and Individual Differences, 9(4), 721726. doi: 10.1016/0191-8869(88)90061-X

Rydstedt, L. W., Cropley, M., Devereux, J. J., \& Michalianou, G. (2009). The effects of gender, long-term need for recovery and trait inhibition-rumination on morning and evening saliva cortisol secretion. Anxiety Stress Coping, 22(4), 465-474. doi: 10.1080/10615800802596378

Schumacker, R. E., \& Lomax, R. G. (2004). A beginner's guide to structural equation modeling. Mahwah, NJ: Erlbaum.

Sencan, H. (2005). Sosyal ve davranışsal ölçümlerde güvenilirlik ve geçerlilik. Ankara: Seckin Yayınevi.

Sonnentag, S., \& Bayer, U. V. (2005). Switching off men- tally: Predictors and consequences of psychological detachment from work during off-job time. Journal of Occupational Health Psychology, 10(4), 393414.

Sonnentag, S. \& Fritz, C. (2007). The recovery experience questionnaire: Development and validation of a measure for assessing recuperation and unwinding from work. Journal of Occupational Health Psychology, 12(3), 204-221. doi: 10.1037/1076-8998.12.3.204

Syrek, C. J., Weigelt, O., Peifer, C., \& Antoni, C. H. (2017). Zeigarnik's sleepless nights: How unfinished tasks at the end of the week impair employee sleep on the weekend through rumination. Journal of Occupational Health Psychology, 22(2), 225-238 doi: 10.1037/ocp0000031

Tabachnick B. G. \& Fidel, L. S. (2001). Using multivariate statistics (4 ${ }^{\text {th }}$ Ed.). Boston, MA: Allyn \& Bacon, Inc.

Thomsen, D. K., Mehlsen, M. Y., Christensen, S., \& Zachariae, R. (2003). Rumination-relationship with negative mood and sleep quality. Personality and Individual Differences, 34(7), 1293-1301. doi: 10.1016/S0191-8869(02)00120-4

Ullman, J. B. (2012). Structural equation modeling. In B. G. Tabachnick \& L. S. Fidel (Eds.), Using multivariate statistics $\left(6^{\text {th }}\right.$ Ed.). Boston, MA: Pearson, Inc.

Warr, P. (1990). The measurement of well-being and other aspects of mental-health. Journal of Occupational Psychology, 63(3), 193-210. doi: 10.1111/j.2044-8325.1990.tb00521.x

Worthington, R. L., \& Whittaker, T. A. (2006). Scale development research: A content analysis and recommendations for best practices. The Counseling Psychologist, 34(6), 806-838. doi: $10.1177 / 0011000006288127$

Zoupanou Z., Cropley M., \& Rydstedt L. W. (2013). Recovery after work: The role of work beliefs in the unwinding process. PLOS ONE, 8(12), 1-9. doi: 10.1371/journal.pone.0081381

\section{İşsel Ruminasyon Ölçeğinin Türkçeye Uyarlama Çalışması}

\section{Giriş}

Mesai bitimindeki zaman bireylerin işleri ile ilgili görev ve sorumluluklarından ayrıştığı bir zaman dilimi olmalıdır. Fakat, birçok birey bu ayrışmayı, yaptığı işin gerekliliklerinden ötürü başaramaz. İşle ilgili düşüncelerden kopamamak ruminasyon olarak tanımlanmıştır (Cropley, Dijk \& Stanley. 2006; Roger \& Jamieson 1988). Ruminasyon alanyazında klinik psikoloji alanında sıklıkla kullanılmıs ve genellikle ruminasyonun duygusal yapısından bahsedilmiştir. Nolen-Hoeksema, Wisco ve Lyubomirsky (2008) ruminasyonu, stress semptomları ve duygulara odaklanarak tekrar eden düşünme süreci olarak tanımlamıştır. Bireylerin işleri ile ilgili ruminatif halleri alanyazında çok yer almaması sebebiyle endüstri psikolojisi alanı bu kavram üzerine dikkat çekmiştir ve iş ile ilgili ruminasyon işsel ruminasyon olarak ele alınmaya başlamıştır. Bireylerin günlerinin üçte birlik kısmını işlerine ayırdıkları göz önüne alındığında (Cropley \& Zijlstra, 2011), işle ilgili konularda ruminatif düşüncede olmaları beklenir. Cropley ve Zijlstra (2011) yazdıkları kitaplarında işsel ruminasyonu iş/işler ile ilgili tekrar eden düşünce/düşünceler olarak tanımlamışlardır. Alanyazında işsel ruminasyonun ölçülmesi için geliştirilmiş birkaç tane ölçek bulunmaktadır (Cropley ve Millward, 2003; Cropley, Michalianou, Pravettoni \& Millward, 2012; Sonnentag \& Fritz, 2007; Warr, 1990). 
Yapılan çalışmalar işsel ruminasyon konusunun önemli olduğunu ortaya koymuştur. Türkiye'de ruminasyon kavramına ilişkin ölçek uyarlama çalışmaları yapılmıştır (Erdur-Baker \& Bugay, 2010; Erdur-Baker \& Bugay, 2012; Karatepe, Yavuz \& Türkcan, 2013); ancak, bu ölçeklerin ruminasyonun duygusal boyutu ile ilgili olduğu görülmektedir. Cropley ve Zijlstra (2011) geleneksel ruminasyonun aksine, ruminasyonun duygusal boyutu ile ilgili, işsel ruminasyonun hem duygusal hem de bilişsel boyutu olduğunu söylemektedir. Araştırmacıların bu söylemi göz önüne alındığında alanyazında iş ile ilgili ruminatif düşüncelerin incelendiği bir araştırmaya rastlanamamıştır. Önceki araştırmalar işsel rumimasyonun farklı değişkenlerle ilişkisi olduğunu ortaya koymuştur; örneğin, uyku düzensizlikleri (Cropley ve dğerleri, 2006; Querstret, Cropley \& Fife-Schaw, 2016; Querstret Cropley, Kruger \& Heron 2015; Syrek Weigelt, Peifer \& Antoni, 2017), yorgunluk (Querstret ve Cropley, 2012; Querstret ve diğerleri, 2015; Querstret ve diğerleri, 2016), kortizol seviyesi (Cropley Rydstedt, Devereux \& Middleton, 2013), iyi oluş hali (Firoozabadi, Uitdewilligen \& Zijlstra, 2016; Hamesch, Cropley \& Lang, 2014; Querstret ve Cropley, 2012; Syrek ve diğerleri, 2017), iş stresi (Hamesch ve diğerleri, 2014), iş inançları (Zoupanou, Cropley \& Rydstedt, 2013), işe bağl1lık (Cropley ve Millward, 2009), ve iş gerginliği (Cropley, Millward-Purvis, 2003; Cropley ve diğerleri, 2006). Çalışan bireylerin ruminatif düşüncelerinin ve bu düşüncelerin sonucu olan değişkenlerin belirlenmesi ve iyileştirme çalışmalarının yapılabilmesi için Türkçe bir ölçeğe ihtiyaç duyulmaktadır. Bu araştırmanın amacı, Cropley ve diğerleri (2012) tarafından geliştirilen işsel ruminasyon ölçeğinin Türk kültürüne uyarlamaktır.

\section{Yöntem}

Araştırma 582 çalışan üzerinde gerçekleştirilmiştir. Katılımcılar, Cropley ve diğerlerinin (2012) çalışmalarında bahsettiği üzere beyaz yakalı çalışanlardan oluşturulmuştur.

Veri toplama aracı olarak Cropley ve diğerleri (2012) tarafindan geliştirilen işsel ruminasyon (IR) ölçeği kullanılmıştır. Toplam 15 madde ve 3 alt boyuttan oluşan ölçek, 5'li Likert tipinde geliştirilmiştir. Ölçekte yer alan birinci, beşinci, yedinci, dokuzuncu ve on beşinci maddeler "duygusal", ikinci, dördüncü, sekizinci, on birinci ve on üçüncü maddeler "problem çözme" ve üçüncü, altınc1, onuncu, on ikinci ve on dördüncü maddeler ise "kopma" alt boyutunu oluşturmuştur.

Araştırmacılar tarafından ölçek Türkçe'ye çevrilmiş ve dil geçerliği çalışmaları yapılmıştır. Ölçeğin dil geçerliğini sağladığı sonucuna varılmıştır. İşsel Ruminasyon Türkçe (IRR-T) ölçeğinin yapı geçerliği için doğrulayıcı faktör analizi ve güvenirliğini belirlemek için Cronbach Alfa kullanılmıştır.

\section{Sonuç ve Tartışma}

Dil geçerliği için İR ve İR-T ölçekleri İngilizce okuduğunu anlama becerisine sahip akademisyenlere üç hafta arayla uygulanmış ve her iki uygulama arasındaki Spearman Brown korelasyon katsayısı hesaplanmıştır. Analiz sonucunda duygusal alt boyutu $(\mathrm{r}=.85 ; p<.05)$, problem çözme alt boyutu ( $\mathrm{r}$ $=.73 ; p<.05)$ ve kopma alt boyutunda $(\mathrm{r}=.62, p<.05)$. ölçeğin dil geçerliğinin olduğu sonucuna varılmıştır.

Doğrulayıcı Faktör Analizinde (DFA) ilk olarak sayıltılar test edilmiştir. 607 katılımcıdan elde edilen veri setinde kayıp veri ve aykırı değer olup olmadığı araştırılmıştır ve 25 katılımcı analizden dışında tutulmuştur. Örneklem büyüklüğ̈̈ > 300 olduğu için yeterli görülmüştür (Worthington ve Whittaker, 2006). Normallik sayıltısı için öncelikle AMOS' da çarpıklık, basıklık ve kritik değerler incelenmiştir. Çok değişkenli normallik için ise Mardia (1970) tarafından geliştirilen çok değişkenli basıklık değeri hesaplanmıştır ve eldeki verinin çok değişkenli normallik gösterdiği sonucuna varılmıştır $(p>.05)$. Çoklu bağlantılılık sayıltısı için varyans artı̧̧ faktörü (VIF) ve tolerans (T) değerleri incelenmiş ve çoklu bağlantılılık sorunu olmadığı saptanmıştır. DFA yapmak için sayıltıların sağlanmasından sonra, üç faktörün gizil değişken, bu faktörleri oluşturan ifadelerin de gösterge değişken olarak yer aldığı 1 . dereceden doğrulayıcı faktör analizi modeli kurulmuştur. İkinci aşamada, model tahminlenirken yapısal eşitlik modellerinde sıklıkla kullanılan ve verilerin normal dağılmadığı durumlarda bile güvenilir sonuçlar veren en çok olabilirlik yöntemi kullanılmış, gözlemlenen değişkenlerin hatalarının, 
gizil değişkenlerin varyansları ve gizil değişkenlerden gözlenen değişkenlere doğru çizilen yollara ilişkin regresyon katsayılarını kapsayan parametrelerin tahmin edilebilmesi amaçlanmıştır. Son aşamada ise üç faktörlü 1 . dereceden oluşturulan doğrulayıcı faktör analizi modeli için uyum indeksleri incelenmiştir. Elde edilen uyum değerlerine bakıldığında, $\chi^{2}$ / sd (4.04), GFI (.92), IFI (.91), CFI (.91), TLI (.91), RMSEA (.072) ve SRMR (.059) değerlerinin iyi olduğu görülmüş ve işsel ruminasyon ölçeğinin 15 ifadeden oluşan 3 faktörlü yapısının (duygusal, problem çözme, kopma) genel olarak iyi uyum sağladığı görülmektedir. İR-T için elde edilen sonuçlar önceki araştırmalarla (Cropley ve diğerleri, 2012; Querstret ve Cropley, 2012) benzerlik göstermiş ve üç boyut doğrulanmıştır.

İR-T ölçeğinin güvenirliğini belirlemek amacıyla Cronbach Alfa katsayısı hesaplanmıştır. Duygusal, problem çözme ve kopma boyutlarının güvenirlikleri sırasıyla $.79, .73$ ve .79 olarak hesaplanmıştır. $\mathrm{Bu}$ değerler daha önceki araştırmalarla benzerlik göstermektedir (Cropley ve diğerleri, 2012; Firoozabadi ve diğerleri, 2018; Hamesch ve diğerleri, 2014; Querstret ve Cropley, 2012; Syrek ve diğerleri, 2017). Uyarlanan ölçeğin güvenirliğinin olduğu sonucuna varılmıştır. Geçerlik ve güvenirlik çalışmaları sonucunda İR-T ölçeğinin Türkçe adaptasyonunun geçerli ve güvenilir olduğu sonucuna varılmıştır. Yapılan araştırmada İR-T ölçeğinin uygulandı̆̆ı grup orijinal ölçektekine benzer şekilde beyaz yakalılardan oluşturulmuştur. Türkiye'deki farklı meslek grupları üzerinde de uyarlanan İR-T formunun uygulanması önerilebilir. 
Appendix A: Regression Weights of T-WRRS CFA Model

Estimate S.E. C.R. P

\begin{tabular}{|c|c|c|c|c|}
\hline <--- Affective & 1,000 & & & \\
\hline $5<--$ Affective & 1,261 &, 100 & 12,652 & **** \\
\hline <--- Affective & 1,250 &, 109 & 11,522 & **** \\
\hline <-- Affective & 1,116 &, 104 & 10,771 & $* * *$ \\
\hline <--- Affective & 1,153 &, 103 & 11,177 & **** \\
\hline <--- Problemsolving & 1,000 & & & \\
\hline <--- Problemsolving & 1,343 &, 127 & 10,557 & **** \\
\hline <--- Problemsolving & 1,229 &, 128 & 9,636 & $* * *$ \\
\hline <-- Probl & 1,110 &, 123 & 9,028 & $* * *$ \\
\hline <--- Problemsolving & 1,169 &, 121 & 9,663 & **** \\
\hline <--- Detachment & 1,000 & & & \\
\hline <--- Detachment & 1,019 &, 059 & 17,154 & $* * *$ \\
\hline <--- Detachment &, 682 &, 057 & 11,884 & **** \\
\hline --- Detachment & 93 &, 062 & 15,069 & $* * *$ \\
\hline (--- Detachment & 611 &, 059 & 10,283 & **** \\
\hline
\end{tabular}

